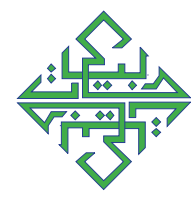

\title{
THE UTILIZATION OF A NEUROLINGUISTIC APPROACH TO STUDENTS FOR ARABIC LANGUAGE LEARNING DEVELOPMENT
}

\author{
Mohammad Jailani, Suyadi, Hendro Widodo \\ Universitas Ahmad Dablan Yogyakarta, Indonesia \\ Jl. Kapas No. 9, Kec. Umbulharjo, Kota Yogyakarta, 55166, Indonesia \\ Corresponding E-mail:mohammad2007052014@webmail.uad.ac.id
}

\begin{abstract}
This study aimed to analyze Arabic language learning with a neurolinguistic approach at SMK Muhammadiyah 3 Yogyakarta. Students have not been able to accept the material presented by the teacher. Students have not responded with their brain intelligence, both in understanding mufradât as well as understanding muhâdatsah. This research used a case study approach, involving the principal, the representative of Ismuba (al-Islam, Kemubammadiyahan, and Arabic Language) and the Arabic language teacher. Data were collected by observation and in-depth interviews. The results of the study prove that the neurolinguistic approach can understand students in mastering Arabic learning through brain synchronization, both right brain, and left brain. Optimizing Arabic language skills rests on his brain. This neurolinguistic approach can facilitate students in mastering istimâ', kalâm, qirâ'ah, and kitâbah abilities in Arabic learning.
\end{abstract}

Keywords: Arabic language learning, neurolinguistics, students development

\section{Introduction}

The main problem of the social facts of this research is based on a preliminary study survey at SMK Muhammadiyah 3 Yogyakarta learning which has not been synchronized with the brain abilities of students, specifically Arabic language learning as a local content subject, making many students less interested in because it is difficult to understand whether it is conversationally (mubâdatsah bi al-mufradât),called active learning, or grammatically (al-Qawâ'id al-'Arabiyah) known as passive learning, this usually happens in formal schools. It is a vocational school that focuses more on theory than practice.

Arabic language learning at SMK Muhammadiyah 3 Yogyakarta, including subjects that are less attractive to students, resulting in students' lack of material 
comprehension. On the one hand, students do not understand hijaijyah letters, read the Qur'an, and Arabic lafąh. based on information from the teacher, precisely in February of the 2020/2021 academic year, the problems that have so far occurred at SMK Muhammadiyah 3 Yogyakarta, are more on how the teachers teach, not how students Arabic language learning. It happens every year in Arabic learning. The learning implemented at SMK Muhammadiyah 3 Yogyakarta is a lecture technique (conventional) with the help of guidebooks or learning modules. Arabic language learning with a neurolinguistic approach is said to be new to students and teachers, especially in educational institutions. The argument is strengthened by Lian Lau's 2021 research, namely Arabic language learning requires a modified and varied approach, just an example of a neurolinguistic approach to learning. Learning that modifies with the right brain and left brain approaches, between mind and language. ${ }^{1}$

Based on observations and informations from teachers at SMK Muhammadiyah 3 Yogyakarta, there are various types of students from public schools. It is known that the majority of students in SMK Muhammadiyah 3 Yogyakarta are dominant from public schools, and many of them are still in the beginning level. Although they are given basic chapters, for example about "ta'âruf" and al-qawâ'id al'Arabiyah, they face it difficult to understand. Moreover, learning at SMK Muhammadiyah 3 Yogyakarta still employed a conventional and module-based learning model. Therefore, it is innovative that to learn with a neurolinguistic approach that focuses on the brain and language skills of students. The implementation of this learning was also still new at SMK Muhammadiyah 3 Yogyakarta,

There has been a growing body of research on Arabic, shown in some research bases, especially on Google Scholar. From 2017 to 2020, many findings lead to learning. However, in this case, the researcher focuses more on Arabic language learning with neurolinguistics which has been also addressed in some previous research. First, Sitohang in his proved that based on statistical tests and teacher responses to the use of information literacy assisted NLP methods. The results of non-parametric statistical test showed the value of sig. $0.000 \%$ so that it can be concluded that there is a significant difference. The teacher's response stated that the NLP method assisted by information literacy helped students increase self-confidence, build motivation, and make it easier for students to achieve learning goals. ${ }^{2}$

The second study by Hilmi found that Arabic grammar learning especially in al-Qawaid Al-Sharfiyah When viewed from a neurolinguistic approach is still less effective in both formal and non-formal schools (Islamic boarding schools). ${ }^{3}$

${ }^{1}$ Yoke Lian Lau, Chek Kim Loi, and Mohd Nor, "The Historical Development of The Study of Broca's Aphasia", Malang Neurology Journal, Vol. 7, No. 2, 2021, 125-128.

2 Kusmadi Sitohang, "Development of Neurolinguistic Programming Methods Assisted by Information Literacy in Speech Learning for High School Students", Thesis, Universitas Pendidikan Indonesia, 2019.

3 Danial Hilmi, “Al-Qawa'id Al-Sharfiyah Learning System in Indonesia in Neurolinguistic Perspective”, Tarbiyatuna, Vol. 2, No. 1, 2017, 140-168. 


\section{Ara6iyât Jurnal Pendidikan Bahasa Arab dan Kebahasaaraban, 8 (2), 2021}

Another research by Ismail indicates that psycholinguistics is very closely related to language teaching and learning activities. In particular, his research is directed at Arabic language learning related to the teaching and learning system of students in terms of psycholinguistics from the psychological aspect and the Arabic language itself. The role of psycholinguistics is related to the elements of Arabic language learning which include objectives, materials, methods, evaluations and the principles of language learning. This was conveyed by Islam, ${ }^{4}$ who relates the object of his research in general to students not limited to the school level, his research was a literature review approach, only supporting research depends on data on library studies. Thus, Ismail's research is in line with this research.

The four relevant studies are previous research, by Fauzi describes that the importance of a neuroscience approach in language curriculum development Arabic is related to optimizing the right and left brain travel system, integrating the role of the brain into the educational and psychological foundations in the form of cognitive, cognitive, and psychomotor aspects, and integrating neuroscience approaches in the development of modern Arabic curriculum. ${ }^{5}$ Fauzi's research is in line with this edintic research that focuses on the neuroscience aspect, namely focusing on the approach of the learner's brain, as a follow-up to this research to maximize neuroscience and Arabic in Arabic language learning. Research that is packaged with neurolinguistics is no longer in curriculum development, but specifically on the Arabic language learning approach that is implemented for students.

Pesenti revealed that "in understanding and easily memorizing numbers in Arabic, a neuroscience approach is needed, a neuroanatomy-based approach by maximizing the prefrontal cortex as the brain's nerve center, which functions as brain intelligence in Arabic numerals, adding Arabic numbers, and mathematics in Arabic". ${ }^{6}$ In line with this research, it is still related to neurolinguistics, but Pasenti's research contribution in this study is related to the prefrontal cortex if this research is more directed towards Arabic language learning in the mufradât aspect, and mubâdatsab in the skills of qirâ'ah, kitâbah, istimá', and kalâm.

Finally, Boudela's study found that Arabic morphology is in line with the science of the brain called morphology as the domain of representation. the neurocognitive function that is supported by brain mechanisms, specifically the prefrontal cortex function, morphology has memory traces in the brain related to the derivative of the word form (wazan). In detail, Boudela relates neuroscience and morphology in the meaning of logic, including magnitude, when viewed from the aspect of neuroscience. However, this study explicitly discusses the neurolinguistic

${ }^{4}$ Mochamad Ismail, "The Role of Psycholinguistics in Arabic Learning”, At-Ta'dib, Vol. 8, No. 2, 2013, 282-297.

${ }^{5}$ Fauzi Muhammad Ilfan, "Utilization of Neuroscience in Arabic Curriculum Development Design," Arabiyatuna, Vol. 4, No. 1, 2020, 1.

${ }^{6}$ Mauro Pesenti et al., "Neuroanatomical Substrates of Arabic Number Processing, Numerical Comparison and Simple Addition: A PET Study", Journal of Cognitive Neuroscience, Vol. 12, No. 4, 2021, 461-479.

7 Sami Boudelaa et al., "Arabic Morphology in the Neural Language System”, Journal of Cognitive Neuroscience, Vol. 22, No. 5, 2010, 998-1010. 
aspects of Arabic language learning, not the morphological aspect or specifically on the Sharf (morphology).

Based on the literature data collection the novelty in this research lies in that this study shed light on an alternative and innovative Arabic language learning with a neurolinguistic approach to student learning problems in schools, especially at SMK Muhammadiyah 3 Yogyakarta. As described and analyzed by the researcher, the similarities of this research are similar to the perspective of neurolinguistics, as an approach in Arabic language learning, both general and Arabic linguistics (al-Qawáid al-Sharfiyah) Arabic language learning at the Islamic-based vocational high school level, namely at SMK Muhammadiyah 3 Yogyakarta. In this study, neurolinguistics is a measure of students' Arabic learning outcomes, and at the same time, a facility to accelerate students' language skills, namely in qirâ'ah, kitâbah, istimá', and kalâm.

With some of the relevant studies showing difference and relevance with this study, it can be concluded in the following figure:

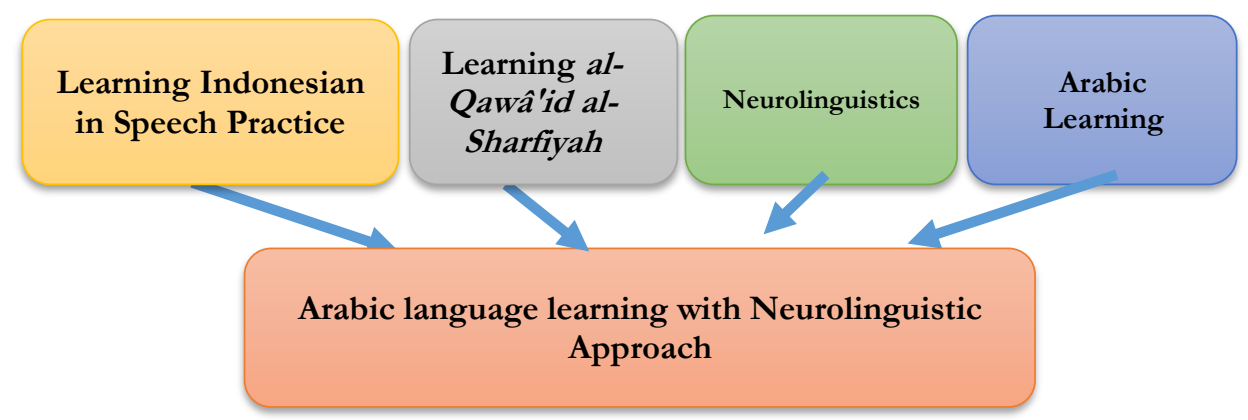

Figure 1. Position of researchers with relevant studies

The figure explains that the position of the researcher with the relevant studies above is that this research covers the development of Arabic learning with a neurolinguistic approach.

The results of previous research studies will also be applied to this study where one of the most related to this research is about learning with a specific neurolinguistic approach to Arabic language learning. Language and neuroscience cannot be separated, in this case as an approach in delivering Arabic learning to students at SMK Muhammadiyah 3 Yogyakarta.

The purpose of this study was to analyze the ability of students to be interested in Arabic language learning. The instruments used in this study were the questionnaires and in-depth interviews with teachers and students at SMK Muhammadiyah 3 Yogyakarta. The main indicators that are expected in this study are the results of students' abilities both in qirâ'ah, kitâbah, istima ', and kalâm abilities, students are expected to be able to read Arabic correctly, as well as write, listen, and speak. However, the indicators are adjusted to the students' basic competence in Arabic language material. Researchers limit the indicators of student achievement to a minimum of students being able to read, write, listen, and speak Arabic. The analysis is by the argument that is not monotonous and feels bored, 


\section{Arabiyât Jurnal Pendidikan Bahasa Arab dan Kebahasaaraban, 8 (2), 2021}

The important role of a brain in students, through a neurolinguistic approach is to affect students' learning in the form of motivation and awareness which is important to learn Arabic. That Arabic is a a tool to communicate and avoid mistakes in speaking. ${ }^{8}$

This research is based on an argument that is relevant today that Arabic language learning with a neurolinguistic approach is very helpful and supportive in Arabic language learning for students at school. Focus on cognitive, affective, and psychometric abilities, specifically on Arabic language skills. As far as Arabic language learning in education, so far it has been less attractive to students' thinking patterns and activities ${ }^{9}$ due to its more emphasis on lectures, writing, and theory, causing students to feel depressed and feel bored.

To be an innovative approach to Arabic language learning towards the implications of Arabic education discourse is a new finding that many scientists and educators have not researched. ${ }^{10}$ This new finding, about the neurolinguistic learning approach, is very helpful in the educational curriculum, and with the latest learning and learning media, teachers are more innovative and creative. Because of a separate motivation in his thinking style, the students are very enthusiastic about Arabic language learning.

\section{Method}

The approach used in this study was qualitative as this study aimed to understand and describe Arabic learning at SMK Muhammadiyah 3 Yogyakarta with a neurolinguistic approach, the approach used to maximize the functions of the right brain and left brain according to the student's brain. The neurolinguistic approach in Arabic language learning is implemented at SMK Muhammadiyah 3 Yogyakarta, to improve students' ability to learn Arabic. In this study, the subjects of this study were teachers and students. Determination of research subjects is done by using a purposive sampling technique. According to Sugiyono, purpose sampling is a sampling technique of data sources with certain considerations. This particular consideration is just an example of the person who is considered to have the most understanding about what is desired, or maybe he is the ruler so that it will make it easier for researchers to explore the object/social situation under study.

Data collection techniques were carried out using interview, observation, and documentation methods. First, in-depth interviews were guided by the interview guide and were not structured to obtain data by asking questions about everything to informants regarding the neurolinguistic approach in Arabic language learning at SMK Muhammadiyah 3 Yogyakarta. The informants were teachers and students. Second,

8 Toto Suharto and Ahmad Fauzi, "Analysis of Syntactic Errors in Arabic Textbooks", Arabiyat, Vol. 4, No. 1, 2017, 20-37.

9 Amal Hashem Khalil, Bahaa El-din Elsayed El-nagar, and Michael Abd El-mesih Awad, "The Effect of Brain-Based Learning on Developing Some Speaking Skills of Egyptian EFL Secondary School Students", International Journal of Environmental \& Science Education, Vol. 14, No. 3, 2019, 103-116.

${ }^{10}$ Wildana Wargadinata et al., "Arabic Creative and Participative Learning: In Search of a New Way of Language Learning by 'El Jidal Reborn' Youth Community in Malang", International Journal of Advanced Science and Technology, Vol. 2, No. 8s, 2020, 4319-4332. 
observation was conducted to obtain information about Arabic language learning with a neurolinguistic approach in Arabic language learning. Third, the documentation, involved in this study were the texts of guide books, modules, and photos of Arabic learning activities. The texts are in the form of Arabic books or Arabic language materials related to Arabic language learning while the photo and recording documents provide visual information about the practical activities of Arabic language learning at this school.

In this study, the type of data analysis used the Miles and Huberman (1994) model, namely the qualitative data analysis was carried out interactively and took place continuously until it was completed and saturated. Activities in data analysis are reduction, display data, and conclusion drawing/verification data. Three main activities are interrelated and occur simultaneously, namely: data reduction, data display, and drawing conclusions or data verification.

\section{Result and Discussion}

\section{Overview of SMK Muhammadiyah 3 Yogyakarta}

SMK Muhammadiyah 3 Yogyakarta is one of the Vocational High Schools located in the city of Yogyakarta, one of the largest and most favorite private Vocational High Schools in the Special area of Yogyakarta City. SMK Muhammadiyah 3 Yogyakarta is a Muhammadiyah charitable educational institution under the auspices of the Directorate General of Primary and Secondary Education for the Muhammadiyah Regional Leadership of Yogyakarta City, in collaboration with the Ministry of Agma and the Ministry and Ministry of Education and Culture. The area of SMK Muhammadiyah 3 Yogyakarta is more than 2 hectares. It is very strategically located in the heart of Yogyakarta, which is north of the Giwangan terminal, Yogyakarta City, Jl. Scout No. 62 Giwangan, Umbulharjo District, Special Region of Yogyakarta. The number of students reached 1. 500 of the total class X. XI and XII. SMK Muhammadiyah 3 Yogyakarta has two learning concentrations, but here students are more directed to the world of practice or the world of vocational and skills. $80 \%$ of learning is modeled practice rather than theoretical given to students.

It has 8 majors of expertise, namely Mechanical Engineering, Architectural Engineering, Computer, and Network Engineering, Audio Visual Engineering, Pharmacy, Motorcycle Engineering, Light Vehicle Engineering, and Electrical Engineering. And supported by training and learning Islamic religious education (alIslam, Kemuhammadiyahan, and Arabic), one of which is that students are directed to Arabic language learning, as a provider of language skills and graduation requirements.

The vision of the Muhammadiyah 3 Yogyakarta Vocational High School is: "a professional center for Arabic language learning and Literacy, especially for students of SMK Mubammadiyah 3 Yogyakarta in general, to the community". The mission of the Muhammadiyah 3 Yogyakarta Vocational High School is to first develop a linguistic program to support Muhammadiyah Islamic education at SMK Muhammadiyah 3 Yogyakarta. Second, providing courses, cycles, and Arabic language training services to support the improvement of the quality of SMK Muhammadiyah 3 Yogyakarta. Third, providing translation services in general and in particular the interests of books 


\section{Arabiyât Jurnal Pendidikan Bahasa Arab dan Kebahasaaraban, 8 (2), 2021}

and Arabic learning modules at SMK Muhammadiyah 3 Yogyakarta. Fourth, cooperate with other linguistic institutions for the realization of the acceleration of the Arabic language program.

\section{Arabic language learning at SMK Muhammadiyah 3 Yogyakarta}

Based on the literature review of the theory that has been explained by the researcher, the researcher emphasizes that the important role of an educator or teacher in schools. Leading to the definition, neurolinguistics is a combination of the roles of a brain in language. ${ }^{11}$ Beforehand, the teacher introduced Arabic language learning through a neurolinguistic approach, it is better to measure the tendencies of students.

Research data including the selection of materials in learning must also be adjusted to the enthusiasm of students, especially in non-ma'bad formal school classes it is usually very difficult to understand immediately. " ${ }^{12}$ "For example, students were chosen with very interesting themes according to their talents and interests. Another thing, perhaps what educators pay more attention to, is to understand the level of ability of their students, for example, if you are still in class X SMK, don't justify being given material about (Alfiyah), it would be better if you were given chapter material (alâmah al-I'râb)". ${ }^{13}$ With this, it is easier to implement a neurolinguistic learning system, with a logical approach to reason and language as the result. $^{14}$

It is very efficient for educators to understand the principles, methods, and objectives of Arabic language learning. Fundamentally, it is known that the Arabic language learning method is a set of techniques used to direct the process of learning activities towards learning objectives as previously set by the Education curriculum. ${ }^{15}$ Regarding the methods that need to be conveyed to students, including the purpose of Arabic language learning, what type of community group the students live in, the level of learning in Arabic (from beginner to advanced), "the characteristics of the students themselves and the dialect or mastery of the material. For example, if in the Java area it is still thick with dialectics, when it is entered in the dialect realm, it is rather difficult to get used to the dialect as usual in Arabic". ${ }^{16}$ Usually, at the SMA/SMK/MA level, it is quite good in grammar or

11 Stephan E. Vogel, Celia Goffin, and Daniel Ansari, "Developmental Specialization of the Left Parietal Cortex for the Semantic Representation of Arabic Numerals: An FMR-Adaptation Study", Developmental Cognitive Neuroscience, Vol. 12, No. 1, 2015, 61-73.

12 Niels O. Schiller, "Neurolinguistic Approaches in Morphology", Oxford Research Encyclopedia of Linguistics, Vol. 1, No. 8, 2020, 1-23.

13 Wahyuningsih, "Inclusive Education For Persons With Disabilities: The Islamic Perspective", QIJIS: Qudus International Journal of Islamic Studies, Vol. 1, No. 4, 2016, 1-18.

14 Wael MY Mohamed, "Arab and Muslim Contributions to Modern Neuroscience", IBRO History of Neuroscience, Vol. 169, No. 3, 2008, 255.

15 Mahmud Kamil Naqah, Tharaiq Tadris al Lughah al Arabiyah Li Ghairi Natiqün Biha, (Kairo: Munazhamah Islamiyah Li Tarbiyah Wa Al Ulum, 2013).

16 Rusydi Ahmad Tu'aimah, Ta'lim Al Arabiyab li Ghair An Natiq biba: Manabijubu wa Asalibubu, (Rabath: ISESCO, 2013). 
(Qawa'id), while what needs to be emphasized is the practice of actively conveying it (bi al-Lughah al-'Arabiyah). ${ }^{17}$

\section{Implications of Neurolinguistics in Arabic Learning at SMK Mubammadiyah 3 Yogyakarta}

Language is a very beautiful gift from God so that humans can manage their minds well, and control the influence of their thoughts from outside that try to influence negative things. ${ }^{18}$ Humans are creatures created by Allah SWT who interact with communication with other creatures. This interaction requires a communication tool called language. According to the Big Indonesian Dictionary, language is a system of arbitrary sound symbols used by the general public to interact and identify. ${ }^{19}$ While in Arabic the meaning and application are certainly very different. Arabic is a tool or language used in today's modern era of globalization, indicating the importance of Arabic language learning in schools and madrasas. Although it is clear in the eyes of the community, especially for educational forums or educational institutions, it still does not encourage or foster a sense of enthusiasm for learning. As experienced in the past, Arabic language learning is not too prioritized, only a complementary material or tool in communicating. ${ }^{20}$ For example, in earlier Arab societies, Arabic was commonly communicated and used in everyday life. Neurolinguistic Arabic learning is Arabic learning that contains elements of Arabic language education material related to the brain on how the brain works (neuroscience).

According to Broca in Akkurt 2021, neurolinguistics is the science that deals with the brain about language. ${ }^{21}$ The brain cannot be used in speaking, because there is an oral that must act speech while the brain is as optimization of thinking in conveying sound or language. ${ }^{22}$ Pasenti 2021 defines neurolinguistics is a learning approach process that involves the brain and tongue sense organs as the basis for thinking and communicating to get the expected results. ${ }^{23}$ Like the following picture:

17 P. McLaren MA Peters, P. Jandri'c, "Viral Modernity? Epidemics, Infodemics, and the 'Bioinformational' Paradigm, Educ. Philos. Theor. 1”, Education, Vol. 1, No. 1, 2020, 1-23.

18 M. Riza Pahlefi, The Relationship between Language and the Brain, nd

${ }^{19}$ L H Santoso, Practical Indonesian Dictionary, (Surabaya: CV. Pustaka Agung Harapan, nd).

20 Toni Pransiska and Sembodo Ardi Widodo, "Ma'âyir Al-Adawât Al-Taqwîmiyah Li Al-Kitâb Al-Madrasî Li Al-Lughah Al-“Arabiyah Li Al-Indûnîsiyîn : Dirâsah Binâiyah Takâmuliyah”, Arabiyat, Vol. 8, No. 1, 2021, 138-156.

21 Ibrahim Onnur Akkurt, "Neurolinguistics: A Spectrum of Research Neurolinguistics: Beer Arastirma Spectrum", Turkish Journal of Educational Research, Vol. 2, No. 1, 2021, $24-27$.

22 Ibrahim Onnur Akkurt, "Neurolinguistics: A Spectrum of Research Neurolinguistics: Beer Arastirma Spectrum," 24-27.

23 Pesenti et al., "Neuroanatomical Substrates of Arabic Number Processing, Numerical Comparison and Simple Addition: A PET Study”, Journal of Cognitive Neuroscience, Vol. 12, No. 3, 2000. 


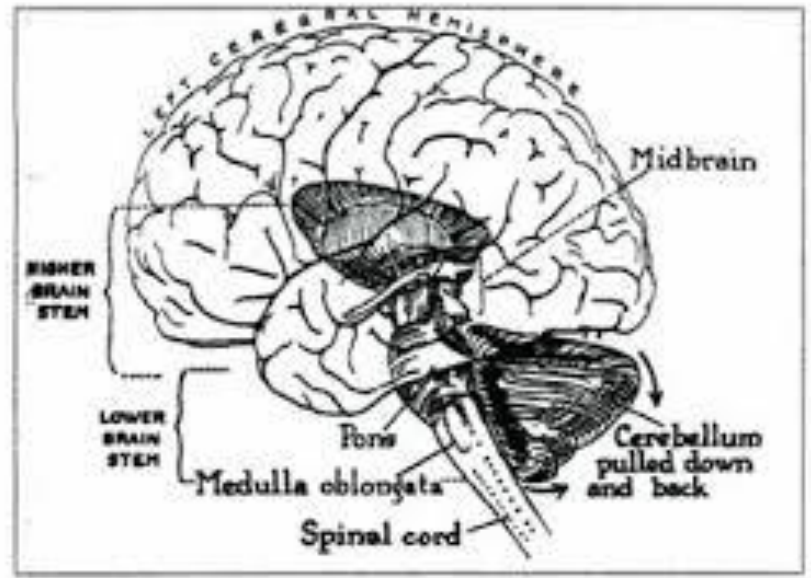

Figure 2. Brain Optimization in Language ${ }^{24}$

According to Paul Broca and Karl Wernicke, neurolinguistics is the main role of the right and left brain responses to the synchronization of the tongue in speech. ${ }^{25}$ In line with Iljina 2021's opinion, neurolinguistics is the main focus of the right brain movement related to the tongue to produce language sounds actively and correctly. ${ }^{26}$ Based on the opinion of the theoretical basis, the researcher concludes that neurolinguistics is a combination of two words, among others, the first comes from the word neuro (neurolinguistics) is a scientific discipline that studies the brain and its functions, and the second is derived from the word linguistics (language), namely the science that discusses language consisting of (phonology, syntax, morphology, and semantics). ${ }^{27}$ It can be understood that neurolinguistics is the study of the brain about language. Testing the learning approach to students through stimulation of the right and left hemispheres of the language, which aims to facilitate students to understand the materials according to their awareness and brain intelligence. ${ }^{28}$ See the following picture:

${ }^{24}$ Tri Budianingsih, "The Role of Neurolinguistics in Language Teaching”, Al-Az̧bar Indonesia Humanities Series, Vol. 3, No. 2, 2015, 137-149.

${ }^{25}$ Iva Ribero Cota, Daniely Martins dos Santos Ferraz, and Nirvana Ferraz Santos Sampaio, "A Narratividade ea Instancia Discurisiva 'Eu' Em Um Estudo Neurolinguistico Sobre Alzheimer's", International Journal Arabic Learning, Vol. 1, No. 2, 2018, 1-18.

${ }^{26}$ Olga Iljina et al., "Neurolinguistic and Machine-Learning Perspectives on Direct Speech BCIs for Restoration of Naturalistic Communication", Brain-Computer Interfaces, Vol. 4, No. 3, 2017, 186-199.

27 Rachel I. Mayberry et al., "Neurolinguistic Processing When the Brain Matures Without Language", Brain Maturation Without Language, Vol. 1, No. 4, 2017, 1-15.

28 Anne L. Beatty-Martínez and Paola E. Dussias, "Revisiting Masculine and Feminine Grammatical Gender in Spanish: Linguistic, Psycholinguistic, and Neurolinguistic Evidence", Frontiers in Psychology, Vol. 10, No. 5, 2019, 1-17. 


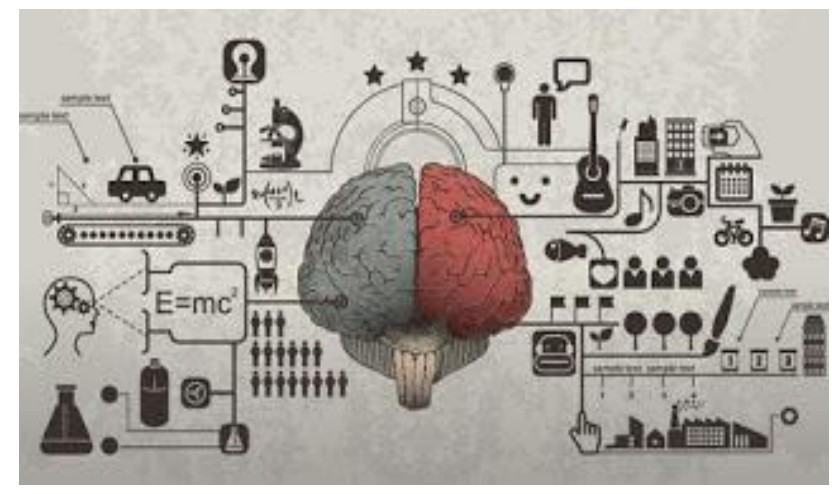

Figure 3. Neuroscience ${ }^{29}$

As mentioned above, neuroscientists study humans as a whole or science that studies humans interdisciplinary. On this basis, the mapping of the scope of neuroscience is none other than humans themselves. However, neuroscience can explore the human dimension in more detail, not only the brain-mind, soul-body, and mind-heart relationships (which have been separate so far), but also probe into very microscopic realms at the cellular-molecular level to behavioral regulation and social science. ${ }^{30}$ One of the organs of the human body that can control all activities significantly in the brain ${ }^{31}$ is a small object weighing approximately $1.5 \mathrm{~kg}$ has 100 billion active nerve cells (neurons) that can process connectivity, including thinking, feeling, seeing, speaking, and creating. ${ }^{32}$ Neurons are the smallest functional parts of the brain that are in charge of transferring signals through electrical work. ${ }^{33}$ Neurolinguistics comes from scientific research that thoroughly discusses the human brain, brain functions, and parts (brain-mind-connection). This means that students in schools are directed to the principles of good (positive) doctrine, maybe even those whose rational brains or brains that function as receivers of intelligence signals have not been used. ${ }^{34}$

According to Karl Wernicke in Ferrytti 2020, neurolinguistic characteristics in the development of Arabic learning include Multiple Intelligence, Emotional Intelligence, Spiritual Intelligence, Adversity Quotient, Brain-Based Learning, and

${ }^{29}$ University of Psychology, "Cognitive Neuroscience: Definition, Studies, and Techniques or Methods", Psychological Science \& Cognitive Psychology, last modified 2018, accessed July 4, 2021, https://www.universitaspsikologi.com/2018/06/neurosains -cognitive-understanding-study.html.

${ }^{30}$ Suyadi, Islamic Education and Neuroscience: Tracing the Traces of Reason and Brain in the Qur'an to the Development of Neuroscience in Islamic Education, (Jakarta: Kencana, 2020).

31 Mayberry et al., "Neurolinguistic Processing When the Brain Matures Without Language".

32 Vogel, Goffin, and Ansari, "Developmental Specialization of the Left Parietal Cortex for the Semantic Representation of Arabic Numerals: An FMR-Adaptation Study".

${ }^{33}$ Helen Abadzi, "How to Speed up Arabic Literacy for Lower-Income Students? Some Insights from Cognitive Neuroscience", How to Speed up Arabic Literacy for Lower-Income Students?, Vol. 1, No. 9 , 2012, 1-23.

${ }^{34}$ Samuel Di Luca et al., "Finger-Digit Compatibility in Arabic Numeral Processing", Quarterly Journal of Experimental Psychology, Vol. 59, No. 9, 2006, 1648-1663. 
Instrumentation. ${ }^{35}$ The research resulted in the development of neuroscience with linguistics in Arabic language learning, giving birth to a process of personality attitude that is not only based on stimuli but also utilizes biological mechanisms that can see how the students' brains work (living brain) by studying them carefully. As we know, the results of this research were investigated with the latest super-sophisticated technologies such as PET (Positron Emission Tomography), SPECT (Single-Photon Emission Computerized Tomography), FMRI (Functional Magnetic Resonance Imaging). ${ }^{36}$

Judging from the basis of the activities of educators in Arabic language learning, the brain's nervous system is the most dominant part in actualizing the framework of thinking and capturing information in language activation. There is no doubt that neurolinguistics in the design of Arabic learning has developed quite rapidly from time to time. One of the pieces of evidence of the role of neurolinguistics in learning is the optimization of the brain as a reflectivity in language responses. In America, the neurolinguistic approach is no longer a scientific discipline but also plays an important role in education specifically towards learning. This is because the purpose of education depends on the object, namely students. While the potential of students relies on how their brains work. ${ }^{37}$ Paul Brocca (2013), explains the three stages of the role of neuroscience related to neurolinguistics in aspects of educational theory including responding and storing information, transforming information into new insightful ideas, and applying ideas in solving problems. ${ }^{38}$

Based on concrete evidence from teachers that holistically and universally "all students still experience difficulties, especially in class X students, this is usually caused by the fact that some students from public schools and public junior high schools are different from Madrasah (tsanawiyah) schools that have been introduced by conversation and mufradât'. In line with the information conveyed by the teacher, it relates to Arabic language learning using the conventional model (lecture technique). Data was taken through a questionnaire at the beginning of February 2021 for the new academic year 2021/2022 by researchers. So it can be described by the table as follows:

Table 1. Language Learning. Arabic with Conventional models

\begin{tabular}{ccc}
\hline Number & Student Learning Ability Results & Presentation \\
\hline 1 & Qirâ'ah ability & $30 \%$ \\
\hline 2 & The ability of the scriptures & $44 \%$ \\
\hline 3 & Special Ability' & $18.7 \%$ \\
\hline 4 & Kalâm Ability & $5.8 \%$ \\
\hline 5 & Mastery of al-Qawâ'id al-'Arabiyah & $3.7 \%$ \\
\hline
\end{tabular}

35 Todd R. Ferretti et al., "How Discourse Constraints Influence Neurolinguistic Mechanisms during the Comprehension of Proverbs," Cognitive, Affective and Behavioral Neuroscience, Vol. 20, No. 3, 2020, 604-623.

36 Todd R. Ferretti et al., "How Discourse Constraints Influence Neurolinguistic Mechanisms during the Comprehension of Proverbs", 604-623.

37 Anurag Tripathi, "Language \& Speech Disorders - It All Starts in the Brain", Science Reporter, Vol. 4, No. 9, 2019, 1-10.

${ }^{38}$ Lau, Loi, and Nor, “The Historical Development of The Study of Broca's Aphasia”. 
From the tabulation of the research results above, it is explained that the mastery of student learning outcomes related to understanding reading, writing, listening, speaking, even in understanding Arabic grammar, is still said to be very minimal the same as the previous year's learning. The lessons taught by the teacher using conventional methods are written, read, and explained. The validation test was strengthened by teacher Asep "why are students in the class still low in Arabic language learning, sir? because many students still can't read, sir, let alone the practice of speaking mubâdatsah is still far away. In addition, the majority of students cannot read the Qur'an, especially regarding the bijailyah letters or Arabic letters one by one. most of the students are also from public schools (state) sir." Learning is also still following the classic way. The curriculum, syllabus, and RPP still adopt the lecture technique, although in the 2013 curriculum many varied ways are modified by the Ministry of Religion General of Islamic education and the Ministry of Education and Culture, especially the Arabic language family. However, most of the teachers have not updated yet."

Based on research evidence from local teacher informants, "in the overall category of vocational high school students from grade X to grade XII, language disorders often occur linguistically in terms of poor phonology (fluent in tajwid) and verbal delivery of letters. This is because the brain has not fully stimulated language speech. And it also happens phonologically, the articulation is quite good and clear even though it often appears in various mentions of language objects. As well as delivery in each (mufradât) and (tarkîb al-kalimah). Significantly it takes time to be efficient in learning it. An effective alternative is none other than a neurolinguistic approach in Arabic language learning".

The researcher conveys and provides Arabic language learning with a neurolinguistic approach, learning that adapts the way students learn to their brains. This means that the student's brain, right brain, and left brain function and relate to each other. An alternative approach and definite steps were taken with the theory or method of neurolinguistics as strategies and methods or accurate in mastering Arabic as a foreign language. "Based on the tendency of the students, which at a glance the researchers peeled a little, that the trend and suitability of students' interests will affect the right brain and left brain functioning each other and, will lead to optimization in critical thinking so that the results reveal the storehouse of memory and language. Because language requires seriousness and repetition in conveying it, speech is not passive or rigid". The following is the student's perception of Arabic language learning with a neurolinguistic approach:

Table. 2 Students' perceptions with a neurolinguistic approach

\begin{tabular}{llc}
\hline Number & \multicolumn{1}{c}{ Student Perception } & Percentage \\
\hline 1 & Very Satisfying Neurolinguistic & $8 \%$ \\
\hline 2 & The suitability of the material with neurolinguistics & $7.5 \%$ \\
\hline 3 & Enough to Meet Language Learning. Arab & $7 \%$ \\
\hline 4 & Less Fulfilling Language Learning. Arab & $5 \%$ \\
\hline 5 & Does not meet Language Learning. Arab & $5 \%$ \\
\hline
\end{tabular}

Based on the tabulation above, students' perceptions of Arabic language learning with a neurolinguistic approach are very enthusiastic. Although there were some students in the questionnaire given by the researcher, they did not fill in and did 
not reveal. Of the 20 students in class X (ten), $80 \%$ of enthusiastic students expect to learn Arabic with a neurolinguistic approach. The data were obtained according to questionnaire data and interviews with teacher information at SMK Muhamamdiyah 3 Yogyakarta. The results of the research assumption data above can be strengthened by research, that teachers and students expect varied learning and by today's learning. One of which is offered by researchers is Arabic language learning with a neurolinguistic approach.

Followed by the learning process of students in class with a neurolinguistic approach, the learning delivered by the teacher $80 \%$ of students responded well, Leading to strong encouragement and strong motivation of the teacher with a right brain and left brain approach in students. The Prefrontal Cortex affects the intelligence center of students and the process of students' emotional intelligence. This can be described below:

Table 3. Students' Ability in the Language Learning Process. Arabic with Neurolinguistics

\begin{tabular}{ccc}
\hline Number & Student Learning Process Ability & Percentage \\
\hline 1 & Very well & $7.5 \%$ \\
\hline 2 & Good & $7 \%$ \\
\hline 3 & Pretty good & $6 \%$ \\
\hline 4 & Not good & $5.2 \%$ \\
\hline 5 & Not good & $5 \%$ \\
\hline
\end{tabular}

Based on the tabulation above, during the learning process, students were active in learning and practicing with their classmates. The teacher tested the chapters and questions in the Arabic subject matter. For example, in the chapter " $t a$ 'âruf" in the first chapter, students were given conversational mufradât material by memorizing some of the mufradat in the book. However, previously students were tried by reading one by one in the textbook followed by memorizing and practicing with eloquent words. Some of the percentages above illustrate that some students need special assistance and guidance stimulated with neurolinguistic and strong motivation by the teacher.

This is in line with the assumption that occurs in the students of "SMK Muhammadiyah 3 Yogyakarta, the ability to communicate is supported by language skills. The complexity of language adapts and follows the accumulation of acquisition which is also interrelated from the simple level to the level that requires language skills and socialization to students of SMK Muhammadiyah 3 Yogyakarta. Psychologically, the needs of the students of SMK Muhammadiyah 3 Yogyakarta in the learning process include a sense of security, comfort, ability, freedom, affection or attention, success, and their existence is recognized. Feelings of security and love are the most important factors in the scope of Arabic language learning".

The neurolinguistic approach has a great impact on the level of inspiration in students' brain abilities in honing Arabic learning particularly students' ability to understand and memorize mufradât, read mufradât and Arabic sentences correctly, and write Arabic with correct imlá ${ }^{\prime}$ skills according to the connection of the hijaijyab letters. Listen to Arabic well, and convey mufradât with fluent speech. Gradually and gradually 
understand Arabic grammar (al-qawâid al-'Arabiyah), finally, some students practice mubahadasab with their friends.

Table 4. Level of Inspiration to Sharpen Arabic Language Skills with Neurolinguistics

\begin{tabular}{clc}
\hline Number & \multicolumn{1}{c}{ Inspirational Level of Student Ability } & Percentage \\
\hline 1 & Ability to Read, Write, mufradât & $8 \%$ \\
\hline 2 & Listening, conveying mufradât & $7 \%$ \\
\hline 3 & Kalam bi al-mufradât & $7 \%$ \\
\hline 4 & Applying the practice of mubâdatsah & $6 \%$ \\
\hline 5 & Understanding al-qawâ'id al-'Arabiyah & $6 \%$ \\
\hline
\end{tabular}

The the tabulation above shows that students were starting to be active in Arabic language learning in the ability to qirâab correctly related to letters, Arabic numbers, or reading Arabic mufradât and lafą̧ . with a percentage of $8 \%$. The ability of the book with the right imla ${ }^{\prime}$ is described by the percentage of $7 \%$ that students still need to keep learning and practicing continuously with a neurolinguistic approach. The ability to convey mufradât and Arabic sentences fluently, students began to improve compared to the previous results. The practice of mubâdatsah with a classmate showed little progress or in the level of improvement. Even though they start with easy material, they take turns with their classmates regarding mubâdatsab in "ta'aruf" material.

Continued with the overall results of students in class X (ten) in Arabic language learning with a neurolinguistic approach. Tabulated data can be generated as follows:

Table 5. Student Results Understand Language. Arabic with Neurolinguistic Approach

\begin{tabular}{|c|c|c|c|c|}
\hline No. & Student Name & Major & \multicolumn{2}{|c|}{ Understand/ No } \\
\hline 1 & Aditya Tegar Grandis Prayoga & $\mathrm{X}$ (Ten) & DPIB & Understand \\
\hline 2 & Ananda Putra Ayogya & X (Ten) & DPIB & Understand \\
\hline 3 & Annisa Cahiya Negari & X (Ten) & DPIB & Understand \\
\hline 4 & Ardian Ilham Primary & X (Ten) & DPIB & Understand \\
\hline 5 & Atha Kurnia & $\mathrm{X}$ (Ten) & DPIB & understand \\
\hline 6 & Aura Shakilla & $\mathrm{X}$ (Ten) & DPIB & understand \\
\hline 7 & Deesca Nafariel M. & X (Ten) & DPIB & understand \\
\hline 8 & Denta Rizky Pewira & $\mathrm{X}($ Ten $)$ & DPIB & understand \\
\hline 9 & Deswita Maharani & $\mathrm{X}($ Ten $)$ & DPIB & understand \\
\hline 10 & Dio Nova Mahendra & $\mathrm{X}$ (Ten) & DPIB & understand \\
\hline 11 & Dito Anggoro Sakti & $\mathrm{X}($ Ten $)$ & DPIB & understand \\
\hline 12 & Fikri Ikhsan Al Muzakkiy & $\mathrm{X}($ Ten $)$ & DPIB & understand \\
\hline 13 & Grechia Alfani Syarla & $\mathrm{X}$ (Ten) & DPIB & understand \\
\hline 14 & Husni Abdul Ghony & $\mathrm{X}($ Ten) & DPIB & understand \\
\hline 15 & Itsna Putri Ramadhani & X (Ten) & DPIB & understand \\
\hline 16 & Ja'far Rizky Fadhilah & X (Ten) & DPIB & No \\
\hline 17 & Jefrino Rico Ferdiansyah & $\mathrm{X}($ Ten $)$ & DPIB & No \\
\hline 18 & Jihan Humaira & $\mathrm{X}($ Ten $)$ & DPIB & No \\
\hline 19 & Marinto Irlan Saputra & $\mathrm{X}$ (Ten) & DPIB & No \\
\hline 20 & Muhammad Sidiq Wibowo & $\mathrm{X}($ Ten $)$ & DPIB & No \\
\hline
\end{tabular}




\section{Arabiyât Jurnal Pendidikan Bahasa Arab dan Kebahasaaraban, 8 (2), 2021}

The tabulation above is the result of student achievement in Arabic lessons. It can be seen that neurolinguistics can stimulate students' interest in Arabic language learning. Neurolinguistics implies that it becomes the strength and capital for mastering Arabic which is relevant to the curriculum and learning in SMK Muhammadiyah 3 Yogyakarta. This cannot be separated from the important role of the teacher. Neurolinguistics facilitates the achievement of students of SMK Muhammadiyah 3 Yogyakarta, as can be seen from the percentage of the results obtained in the table above. Of the 20 students who did not understand the Arabic language learning delivered, only a few students did not understand related to the learning of mufradat and mubadatsah, both the application of the language skills of qirâ'ah, kitâbah, istimâ', and kalam as well as the application of learning to practice speaking or conversation. However, some percentage of the results of student understanding, there are weaknesses. Weaknesses against students, 5 students were still low and have not mastered Arabicin term of the ability of qirâ'ah, kitâbah, istimá', kalam, and al-qawâ'id al-Arabiyah. The need for a neurolinguistic approach was continued in implementing Arabic learning as an evaluation in Arabic language learning with a neurolinguistic approach, explicitly in this study.

The steps for Arabic language learning with a neurolinguistic approach at SMK Muhammadiyah 3 Yogyakarta are as follows:

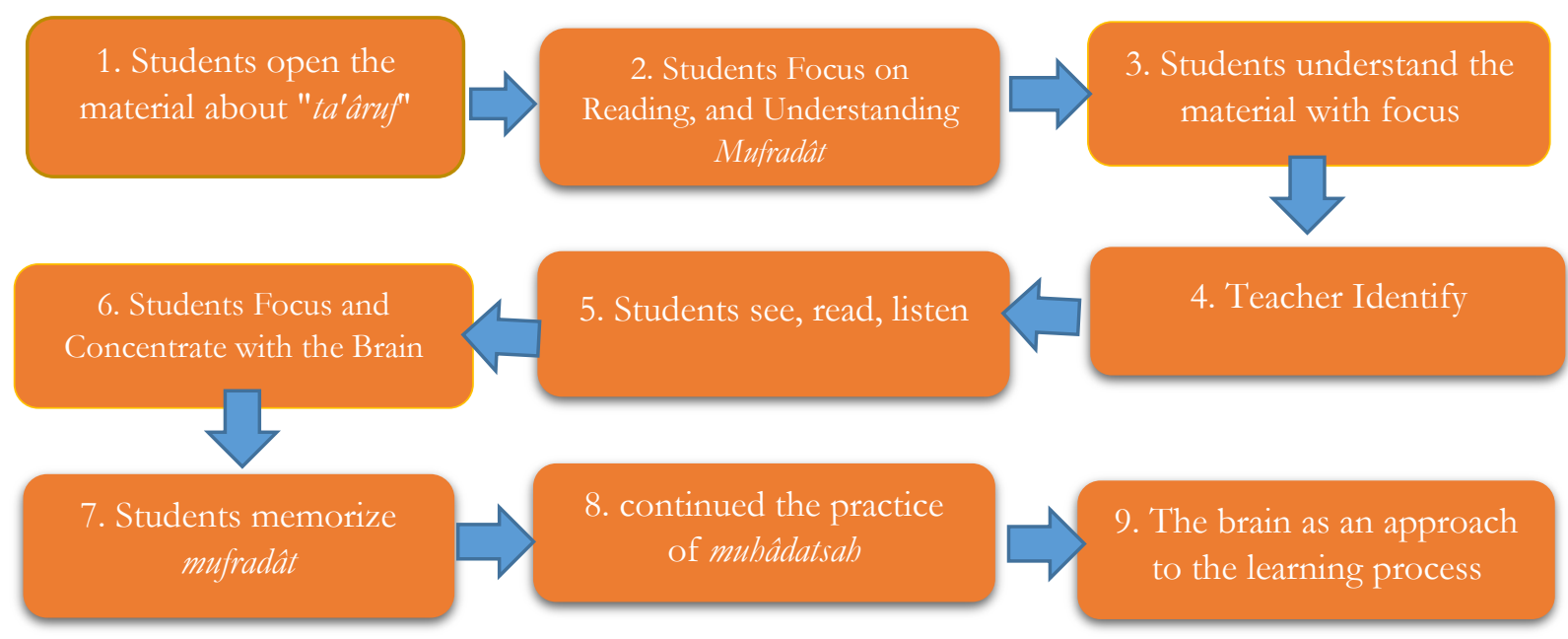

Figure 4. The flow of Steps of Neurolinguistic Approach.

The steps above for the neurolinguistic approach in Arabic language learning can be described as follows:

1. Students open the material in the guidebook or Arabic language module, according to the chapters and basic competencies on "ta'aruf" by the teacher.

2. Students see the reading delivered by the teacher in the material

3. Students understand the material mufradât and mubâdatsah.

4. Students concentrate with the brain and respond with the language to be spoken. 
5. Students see, read, listen, and practice what the teacher says in Arabic textbooks.

6. The teacher identifies students who cannot read and students who can read Arabic mufradât.

7. Students are directed to memorize five mufradât and asked to practice saying them, according to the material mufradat.

8. The students continued to practice mubâdatsah with their classmates, and understand al-qawa'id al-'Arabiyah related to the nabw-sharf material. Both in the form of words and the arrangement of sentences in the I'rabnya.

9. Right brain and left brain are maximized in the process of Arabic language learning language learning, Arabic language learningin order to make learning easily accepted and responded to by students as fun learning leads to the student's brain. In the ability to learn qirâah, kitâbah, istimâ', kalâm and muhâdatsah, Arabic grammar in its nabw-sharf, and ended with a learning evaluation.

\section{Conclusion}

Based on the results of research and discussion, it turns out that Arabic language learning in SMK Muhammadiyah 3 Yogyakarta which is applied to students produces different data and information. Starting with the findings of Arabic language learning using conventional models or lecture techniques, there are very low student learning outcomes. Students' abilities in qirâ'ah, kitâbah, istimâ', kalâm, and muhâdatsah practices are less than optimal, coupled with a less than optimal understanding of alqawa'id al-'Arabiyah. This is in line with the results of the questionnaire submitted by the researcher, that teachers and students expect varied learning and have good implications for the development of student learning outcomes.

The neurolinguistic approach implemented at SMK Muhamamdiyah 3 Yogyakarta helped students learn Arabic, in that it maximized the right brain and left brain explicitly on the students' prefrontal cortex as the brain center of students' intelligence in understanding Arabic material. Several factors support students to apply the neurolinguistic approach to the compatibility approach between language and thought. It is proven by the results of the population and instrument data given by the researcher to students and teachers. From student reception data, students' inspiration in honing Arabic, and finally the overall results of students related to understanding or not Arabic language learning. The neurolinguistic approach can make it easier for students to understand the material presented by the teacher as an optimization of the brain in language according to students' Arabic abilities in affective, cognitive, and psychomotor because students no longer have difficulty Arabic language learning. Based on the results of the research in the tabulation and questionnaire above, $80 \%$ of students were able to understand the process of running the material well. 15 students have understanding the material of the book, qirâah, kitâbah, istimâ', kalâm, and muhâdatsah, understanding in al-qawâid al-Arabiyah. However, 5 students need intensive assistance and special guidance from the teacher in a neurolinguistic approach. Of course, this is an evaluation in Arabic language learning with a 


\section{Arabiyât Jurnal Pendidikan Bahasa Arab dan Kebahasaaraban, 8 (2), 2021}

neurolinguistic approach, specifically in this study.

This study has limitations both in content and analysis of the main substance. For example, This study was conducted in only one school in Yogyakarta, researchers have not collaborated neurolinguistics with the understanding of the Qur'an in Arabic related to interdisciplinary, transdisciplinary, and multidisciplinary in Arabic education discourse. The researcher therefore recommends further research to find a comprehensive Arabic learning model, just an example of interpretation-based Arabic learning that all materials are related to the verses of the Qur'an to bring students closer to the Qur'an or Ibn Sina's multilevel reasoning approach because the researcher realizes that there are no researchers who lead the research base. Research that has broad implications for Arabic learning discourse, especially nowadays online, in a time of increasing development and technology, especially during the COVID-19 period.]

\section{REFERENCES}

Abadzi, Helen. "How to Speed up Arabic Literacy for Lower-Income Students? Some Insights from Cognitive Neuroscience", How to Speed up Arabic Literacy for Lower-Income Students?, Vol. 1, No. 9, 2012.

Akkurt, Ibrahim Onnur. "Neurolinguistics: A Spectrum of Research Neurolinguistik: Bir Arastirma Spektrumu”, Turkish Journal of Educational Research, Vol. 2, No. 1, 2021.

Beatty-Martínez, Anne L., and Paola E. Dussias. "Revisiting Masculine and Feminine Grammatical Gender in Spanish: Linguistic, Psycholinguistic, and Neurolinguistic Evidence", Frontiers in Psychology, Vol. 10, No. 5, 2019.

Boudelaa, Sami., Friedemann Pulvermüller, Olaf Hauk, Yury Shtyrov, and William MarslenWilson. "Arabic Morphology in the Neural Language System", Journal of Cognitive Neuroscience, Vol. 22, No. 5, 2010.

Budianingsih, Tri. "Peran Neurolinguistik Dalam Pengajaran Bahasa", Al-Az̧ar Indonesia Seri Humaniora, Vol. 3, No. 2, 2015.

Cota, Iva Ribero., Daniely Martins dos Santos Ferraz, and Nirvana Ferraz Santos Sampaio. “A Narratividade e a Instancia Discurisiva 'Eu' Em Um Estudo Neurolinguistico Sobre Alzheimer", International Journal Arabic Learning, Vol. 1, No. 2, 2018.

Di Luca, Samuel., Alessia Granà, Carlo Semenza, Xavier Seron, and Mauro Pesenti. "FingerDigit Compatibility in Arabic Numeral Processing", Quarterly Journal of Experimental Psychology, Vol. 59, No. 9, 2006.

Fauzi Muhammad Ilfan. "Pemanfaan Neurosains Dalam Desain Pengembangan Kurikulum Bahasa Arab”, Arabiyatuna: Jurnal Bahasa Arab, Vol. 4, No. 1, 2020.

Ferretti, Todd R., Albert N. Katz, Christopher A. Schwint, Courtney Patterson, and Dagna Pradzynski. "How Discourse Constraints Influence Neurolinguistic Mechanisms during the Comprehension of Proverbs", Cognitive, Affective and Behavioral Neuroscience, Vol. 20, No. 3, 2020.

Hilmi, Danial. "Sistem Pembelajaran Al-Qawa'id Al-Sharfiyah Di Indonesia Dalam Perspektif Neurolinguistik", Tarbiyatuna, Vol. 2, No. 1, 2017. 


\section{Arabiyât Jurnal Pendidikan Bahasa Arab dan Kebahasaaraban, 8 (2), 2021}

Iljina, Olga., Johanna Derix, Robin Tibor Schirrmeister, Andreas Schulze-Bonhage, Peter Auer, Ad Aertsen, and Tonio Ball. "Neurolinguistic and Machine-Learning Perspectives on Direct Speech BCIs for Restoration of Naturalistic Communication", Brain-Computer Interfaces, Vol. 4, No. 3, 2017.

Ismail, Mochamad. "Peranan Psikolinguistik Dalam Pembelajaran Bahasa Arab", At-Ta'dib, Vol. 8, No. 2, 2013.

Khalil, Amal Hashem., Bahaa El-din Elsayed El-nagar, and Michael Abd El-mesih Awad. "The Effect of Brain-Based Learning on Developing Some Speaking Skills of Egyptian EFL Secondary School Students", International Journal of Environmental \& Science Education, Vol. 14, No. 3 , 2019.

Lau, Yoke Lian., Chek Kim Loi, and Mohd Nor. "The Historical Development of The Study of Broca's Aphasia”, Malang Neurology Journal, Vol. 7, No. 2, 2021.

Mayberry, Rachel I., Tristan Davenport, Austin Roth, and Eric Halgren. "Neurolinguistic Processing When the Brain Matures Without Language", Brain Maturation Without Lanaguage, Vol. 1, No. 4, 2017.

Mohamed, Wael M Y. "Arab and Muslim Contributions to Modern Neuroscience", IBRO History of Neuroscience, Vol. 169, No. 3, 2008.

Pahlefi, M. Riza. Hubungan Bahasa Dengan Otak. n.d.

Peters, M.A., P. Jandri'c, P. McLaren. "Viral Modernity? Epidemics, Infodemics, and the 'Bioinformational' Paradigm, Educ. Philos. Theor. 1", EDUCATION, Vol. 1, No. 1, 2020.

Pesenti, Mauro., Marc Thioux, Xavier Seron, and Anne De Volder. "Neuroanatomical Substrates of Arabic Number Processing, Numerical Comparison and Simple Addition: A PET Study", Journal of Cognitive Neuroscience, Vol. 12, No. 4, 2021.

Pransiska, Toni., and Sembodo Ardi Widodo. "Ma'âyir Al-Adawât Al-Taqwîmiyah Li Al-Kitâb Al-Madrasî Li Al-Lughah Al-'Arabiyah Li Al-Indûnîsiyîn : Dirâsah Binâiyah Takâmuliyah", Arabiyat: Jurnal Pendidikan Bahasa Arab dan Kebahasaaraban, Vol. 8, No. $1,2021$.

Santoso, LH. Kamus Praktis Bahasa Indonesia. Surabaya: CV. Pustaka Agung Harapan, n.d.

Schiller, Niels O. "Neurolinguistic Approaches in Morphology", Oxford Research Encyclopedia of Linguistics, Vol. 1, No. 8, 2020.

Sitohang, Kusmadi. "Pengembangan Metode Pemrograman Neurolinguistik Berbantuan Literasi Informasi Dalam Pembelajaran Berpidato Siswa Sekolah Menengah Atas", Thesis, Universitas Pendidikan Indonesia, 2019.

Suharto, Toto., and Ahmad Fauzi. “Analisis Kesalahan Sintaksis Dalam Buku Teks Bahasa Arab”, Arabiyat: Jurnal Pendidikan Bahasa Arab dan Kebahasaaraban, Vol. 4, No. 1, 2017.

Suyadi. Pendidikan Islam Dan Neurosains: Menelusuri Jejak. Akal Dan Otak Dalam Alquran Hingga Pengembangan Neurosains Dalam Pendidikan Islam. Jakarta: Kencana, 2020.

Tripathi, Anurag. "Language \& Speech Disorders - It All Starts in the Brain", Science Reporter, Vol. 4, No. 9, 2019.

Tu'aimah, Rusdi. Ta'lim Al Arabiyah li Ghair An Natiq biba: Manabijubu wa Asalibubu. Rabath: ISESCO, 2013. 
Vogel, Stephan E., Celia Goffin, and Daniel Ansari. "Developmental Specialization of the Left Parietal Cortex for the Semantic Representation of Arabic Numerals: An FMRAdaptation Study”, Developmental Cognitive Neuroscience, Vol. 12, No. 1, 2015.

Wahyuningsih. "Inclusive Education For Persons With Disabilities: The Islamic Perspective", QIJIS: Qudus International Journal of Islamic Studies, Vol. 1, No. 4, 2016.

Wargadinata, Wildana., Iffat Maimunah, Saidna Zulfiqar Bin Tahir, and M Chairul Basrun Umanailo. "Arabic Creative and Participative Learning: In Search of a New Way of Language Learning by 'El Jidal Reborn' Youth Community in Malang”, International Journal of Advanced Science and Technology, Vol. 2, No. 8s, 2020. 